\title{
Movement and Mortality of Adult Brown Trout in the Motupiko River, New Zealand: Effects of Water Temperature, Flow, and Flooding
}

\author{
Roger G. Young, ${ }^{*}$ Jeremy Wilkinson, ${ }^{1}$ Joe Hay, and John W. Hayes \\ Cawthron Institute, Private Bag 2, Nelson, New Zealand
}

\begin{abstract}
Management of the effects of water quality and flow on fisheries requires an understanding of the factors that control fish movements. We used radiotelemetry to monitor the movements of adult brown trout Salmo trutta in a New Zealand river over 11 months (September 2004 to August 2006) and linked those movements to the changes in flow and water temperature. Individual fish moved up to $41 \mathrm{~km}$ during the study. However, most fish moved less than $1 \mathrm{~km}$. All of the trout that showed little movement throughout the summer were living in relatively deep pools that presumably provided cover. The rates of movement declined steadily over the spring-summer period, as flow decreased and water temperature increased. The percentage of fish moving was positively related to the average daily flow during the interval between tracking occasions and negatively related to the average daily water temperature, less than $20 \%$ of the tagged fish moving once temperatures were above $19^{\circ} \mathrm{C}$. A severe, 50-year flood occurred in March 2005 and was associated with the mortality of $60-70 \%$ of the remaining tagged fish, confirming that flood-induced mortality can affect a substantial proportion of an adult brown trout population.
\end{abstract}

Research on river-resident salmonids over the last 15 years has indicated that widespread movement is much more common than previously thought (Gowan et al. 1994; Young 1996; Young et al. 1997; Diana et al. 2004; Mellina et al. 2005; Heggenes et al. 2007). Movement can be within an extended home range of several hundred meters (Rodriguez 2002; Diana et al. 2004; Mellina et al. 2005; Roghair 2005) up to largerscale movements of many kilometers (Clapp et al. 1990; Bettinger and Bettoli 2004; Gresswell and Hendricks 2007; Heggenes et al. 2007). Large-scale movements can be important for providing valuable permanent or seasonal fisheries in particular reaches of rivers (Meyers et al. 1992; Meka et al. 2003) and also help explain patterns in size distribution of fish throughout catchments (Hughes 1999).

One of the main reasons for large-scale trout

\footnotetext{
* Corresponding author: roger.young@cawthron.org.nz

${ }^{1}$ Present address: Public Research Centre Henri Tudor, Technoport Schlassgoart, P.O. Box 144, L-4002 Esch-surAlzette, Luxembourg.
}

Received July 21, 2008; accepted July 22, 2009

Published online November 5, 2009 movement is to seek spawning habitat (Northcote 1992). However, the importance of spawning migrations in river trout populations probably depends on the location of good spawning gravels relative to the position of good adult trout habitat (Northcote 1992). Trout may also move to seek better food resources and feeding habitat or thermal conditions so they can maximize their energy intake and growth potential (Gowan and Fausch 2002; Hughes 1998, 1999; Hughes et al. 2003). Water temperature is a key variable controlling trout growth and survival. If it is too cold, trout will stop growing; however, high temperatures will also restrict growth and increase mortality (Elliott 1994). Trout also seek refuge from adverse environmental conditions in winter (Cunjak 1996) and summer (Nielsen et al. 1994; Ebersole et al. 2003). Floods may also initiate longitudinal or lateral movement in fish, either to take advantage of easier passage during high flow conditions (Dedual and Jowett 1999; Natsumeda 2003) or in an effort to avoid the impact of floods (Jowett and Richardson 1994; Schwartz and Herricks 2005).

Juvenile trout abundance tends to decline after severe floods (Jowett and Richardson 1989; Hayes 1995; Harvey et al. 1999; Nislow et al. 2002). However, the effects of floods on adult trout appear to be less severe and unpredictable (Allen 1951; Seegrist and Gard 1972; Jowett and Richardson 1989; Lobon-Cervia 1996). Some studies have indicated that adult and juvenile trout displaced downstream by floods have returned upstream during the flood recession (Dedual and Jowett 1999; Dare et al. 2002; Ortlepp and Murle 2003). Therefore, it is not clear whether the reduction in abundance associated with floods observed in some studies is due to displacement or direct flood-induced mortality. As far as we are aware there are few direct observations of trout mortality resulting from floods (Ortlepp and Murle 2003).

In this study we used radiotelemetry to monitor movements of 48 adult brown trout Salmo trutta over an 11-month period, and to link trout movements with patterns of flow and water temperature. We also report 
on the effects of a large flood on mortality of the radiotagged fish.

\section{Methods}

Study site.-The Motupiko River drains a 344-km² catchment and joins the Motueka River $55 \mathrm{~km}$ upstream from the sea. The river has an annual mean flow of $5.2 \mathrm{~m}^{3} / \mathrm{s}$ and median flow of $2.5 \mathrm{~m}^{3} / \mathrm{s}$. The wetted channel width at low flow ranges from 6 to 18 $\mathrm{m}$. The mean annual low flow is $0.5 \mathrm{~m}^{3} / \mathrm{s}$, but during severe droughts there is no surface flow in the reach upstream of the confluence with the Motueka River. The Motupiko River is considered to be an important spawning and rearing area that contributes to the internationally recognized brown trout fishery in the Motueka River (Basher 2003). The brown trout population in the Motueka catchment is self-sustaining; fish move from the main stem of the river to tributaries like the Motupiko for spawning in late autumn and early winter (April-June). After spawning some of these fish take up residence in the tributaries. The Motupiko River itself supports a regionally important fishery for brown trout in spring and early summer, but anglers do not rate it so highly in summer and autumn when flows drop and water temperatures increase, suggesting that trout may move downstream out of the Motupiko River (Richardson et al. 1984). The trout are primarily river resident with no confirmed incidence of sea running (Olley 2008). Dive surveys in the Motupiko River have found between 3 and 61 adult trout per kilometer (Fish and Game New Zealand, unpublished data).

Radio-tagging.-Local expert anglers caught 48 brown trout from a $25-\mathrm{km}$ stretch of the Motupiko River (Figure 1) between 20 September and 5 November 2004, which we subsequently radio-tagged. Once hooked, the time required to land the fish was minimized to limit stress. The fish were transferred to flow-through, vinyl holding bags, similar to those described by Venman and Dedual (2005), until they could be surgically implanted with radio tags (methods of Dedual and Jowett 1999). Following surgery, trout were placed in a large bin of freshwater, carried back to the river, and transferred to a holding bag. The holding bags were positioned in actively flowing water, and the fish oriented to face upstream. They were then left for 15-20 min in the bag to recover. All fish were released at their respective capture sites once they were strong enough to swim vigorously and had regained their full color. No fish died during capture or surgery.

The transmitters $(48 \times 18 \mathrm{~mm}, 220-\mathrm{mm}$ antenna) weighed $19 \mathrm{~g}$ (in air), which represented $0.7-2.4 \%$ of the body weight of the $0.8-2.6-\mathrm{kg}$ trout (mean 1.74 $\mathrm{kg}$ ), a percentage considered to have no effect on fish swimming performance, condition, or growth (Brown et al. 1999; Jepsen et al. 2002; Brown et al. 2006). It is possible that the trout exhibited unnatural behavior for a short period after tagging (e.g., Walker et al. 2000), but this would presumably only affect results from the first tracking occasion, which occurred $12 \mathrm{~d}$ after the last fish was tagged. The tags transmitted signals with frequencies of 160.121 to $161.102 \mathrm{MHz}$, in approximately $20 \mathrm{KHz}$ steps, so each fish could be identified by its specific frequency. The exact frequency of the signal from each tag was checked before the tags were implanted. The tags were supplied by Sirtrack (http:// www.sirtrack.com), and the batteries were expected to last for 12 months.

Radio tracking.-Using an ATS R2100 scanning receiver with a three-element Yagi folding antenna, we tracked the radio-tagged fish by foot along a 22-km reach from the confluence of the Motupiko and Motueka rivers to the confluence of the Rainy and Motupiko rivers (Figure 1). Each radio-tracking occasion took $2 \mathrm{~d}$ to cover the $22 \mathrm{~km}$ reach and was conducted approximately every fortnight from November 2004 to April 2005 and twice over the period from May to August 2005. Tracking on foot was found to be effective at determining accurate locations of fish and allowed for visual confirmation that the signal was coming from a live fish in most instances. Fish locations were recorded using a Global Positioning System (GPS; Garmin GPS 12) that was expected to have an accuracy of approximately $15 \mathrm{~m}$ according to the manufacturer's specifications.

Aerial tracking was also conducted three times in 2005 (15 February, 8 April, and 22 July) from a fixed wing plane, which had mounting brackets on each wing to hold the Yagi antennae. Aerial tracking covered all the major waterways in the Motueka catchment from the river mouth to the headwaters. The location of trout tracked from the plane was subsequently confirmed by ground surveys.

Environmental measurements.-A temperature logger deployed in the Motupiko River downstream of the Rainy River confluence (Figure 1) recorded temperatures every 30 min during the study. A flow record from the Motupiko River at Christies Bridge (Figure 1) was supplied by the Tasman District Council.

Analysis. - The rate of movement for individual fish was estimated by dividing the distance moved between tracking occasions by the number of days since the previous record. Trout could actually move at a greater or lesser rate for periods within the tracking interval. The greater the time between tracking occasions, the less likely it is that movement rates realistically describe the dynamics of movement (Ovidio et al. 2000). Total recorded movement for each fish was the 


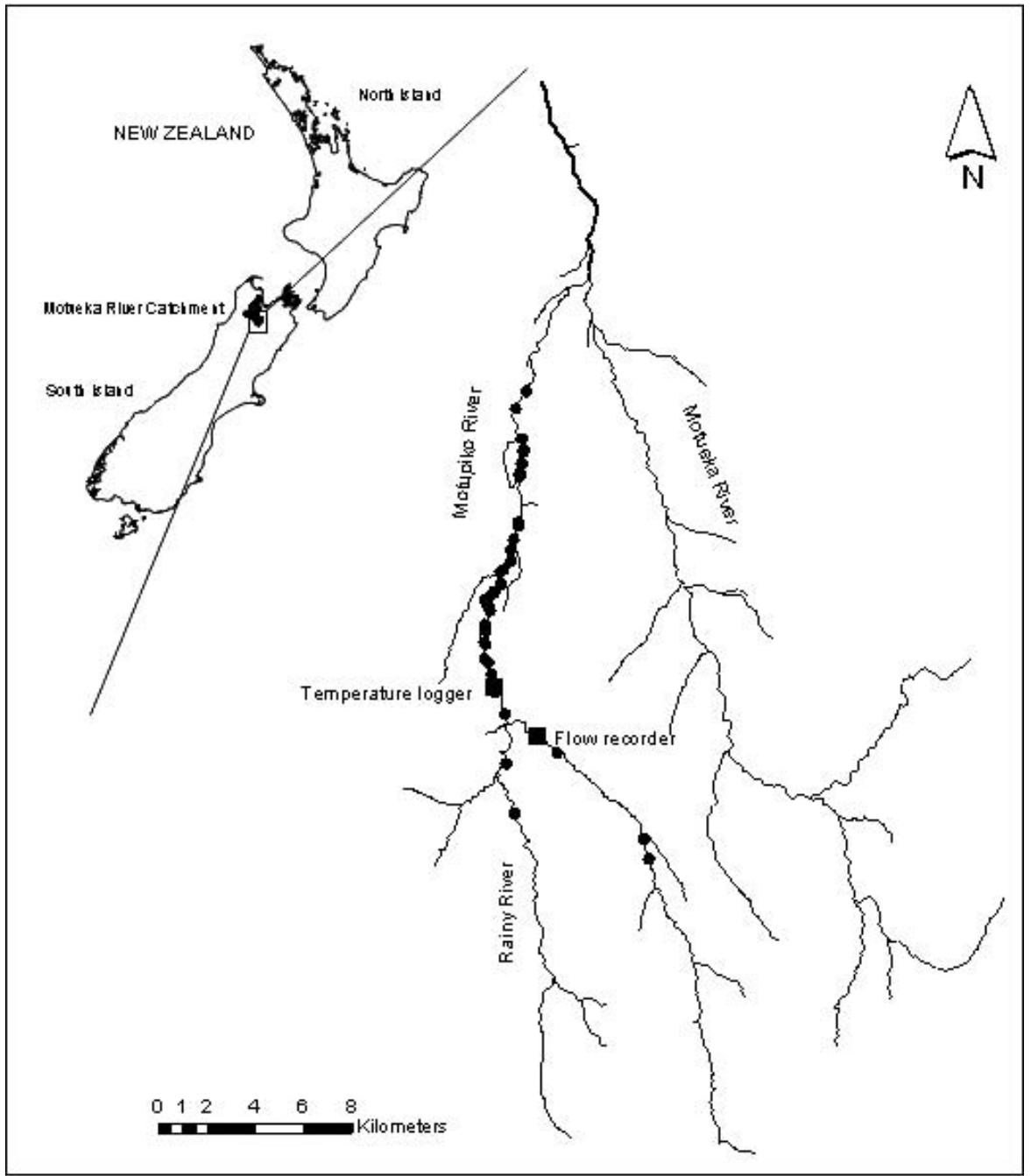

FIGURE 1.- Initial release points for brown trout fitted with radio transmitters (circles) in the Motupiko River and locations of the water flow and temperature loggers.

sum of all recorded movements, both upstream and downstream, during the study.

When examining general changes in fish location on each tracking occasion, the small number of longdistance shifts introduced extreme bias in the arithmetic mean location change. To overcome this bias we estimated the geometric mean, which gives a better measure of central tendency for a log-normally distributed sample. Based on the expected accuracy of the GPS, we considered any change in fish location greater than $15 \mathrm{~m}$ between radio-tracking occasions to represent a real movement. Relationships between movement rates, the percentage of fish moving, and flow and temperature data were assessed with simple linear regression. Data were $\log _{e}$ or arcsine transformed where appropriate to improve normality. Data on movement rates after the large flood were not included in the analysis due to the small number of live fish remaining.

\section{Results}

\section{Trout Capture and Tracking}

Of the 48 adult trout captured from the Motupiko and Rainy rivers, there was a strong bias toward males: only $11(23 \%)$ were female. Male and female trout had a similar mean weights (1.76 versus $1.64 \mathrm{~kg}$ ) and lengths (555 versus $538 \mathrm{~mm}$ ). After release, 44 of the trout were successfully relocated between 1 and 13 
times during the study (mean, 7.3 times). Four fish were never relocated, and 22 were permanently lost at some stage during the study. The aerial tracking surveys covered all the main waterways throughout the entire catchment and successfully located 5 tagged fish outside the reach surveyed by foot. Given the relatively small number of trout found outside the standard survey reach, we consider that premature transmitter failure, rather than predation or large-scale migration to the sea, was the most likely cause of failure to relocate fish. Transmitters from two fish were handed in by anglers, and a dead fish with a transmitter was handed in by a local farmer. Four other fish were found dead during radio-tracking preceding the large flood.

\section{Changes in Fish Location}

Total recorded trout movement varied from $15 \mathrm{~m}$ to $41.4 \mathrm{~km}$ among individual fish during the study (Figures 2,3). Most of the tagged fish moved only a short distance during the study, around $64 \%$ moving less than $1,000 \mathrm{~m}$. Rates of movement ranged from 0 to $801 \mathrm{~m} / \mathrm{d}$ and averaged $22.5 \mathrm{~m} / \mathrm{d}$, although this mean was heavily skewed by the largest movements. The geometric mean movement rate was $0.68 \mathrm{~m} / \mathrm{d}$.

Of the fish that moved substantial distances, three fish moved more than $5 \mathrm{~km}$ downstream having earlier occupied a small section $(<100 \mathrm{~m})$ of river. Another three fish settled into specific locations after moving many kilometers downstream (Figure 2). One fish remained near its release location for the 4 months after tagging, then abruptly moved $10 \mathrm{~km}$ downstream in early January, remaining there for 2 months before returning upstream to its original location.

\section{Position Changes Related to Flow and Water Temperature}

Rates of movement were initially relatively high, before declining to almost zero over the summer. Following the flood in March 2005, the remaining fish also had relatively high rates of movement, which perhaps was related to spawning activity. Geometric mean movement rates on each tracking occasion for all tagged trout were positively related with average daily flow at the Motupiko flow recorder during the interval between tracking occasions $\left(R^{2}=0.48, F=9.3, P=\right.$ $0.01)$. Similarly, the percentage of fish moving $(>15$ $\mathrm{m})$ between each tracking period showed a positive relationship with average daily flow (arcsine-squareroot transformed data, $R^{2}=0.66, F=15.8, P=0.004$; Figure 4).

There was no significant relationship between the geometric mean rate of movement on each tracking occasion for all tagged trout and average daily water temperature in the Motupiko River. The percentage of fish moving more than $15 \mathrm{~m}$ between each tracking period showed a negative relationship with average daily water temperature (arcsine-square-root transformed data, $R^{2}=0.58, F=11.2, P=0.01$; Figure 4). Most fish moved when water temperatures were less than $15^{\circ} \mathrm{C}$, but the percentage of the tagged fish moving declined steadily above this temperature; less than $20 \%$ of the tagged fish moved once temperatures were above $19^{\circ} \mathrm{C}$.

\section{Fish Mortality and Flooding}

An intense, but localized, storm hit the Motupiko catchment on 25 March 2005: about $170 \mathrm{~mm}$ of rainfall in $4 \mathrm{~h}$ (Tasman District Council, unpublished data). Instantaneous flows at the Motupiko flow recorder rose from $0.53 \mathrm{~m}^{3} / \mathrm{s}$ to a maximum of $166 \mathrm{~m}^{3} / \mathrm{s}$ over a period of $9 \mathrm{~h}$, the highest flow recorded at this site since recording began in 1990; the flow had an estimated annual exceedance probability of 2\% (50year return period, Tasman District Council, unpublished data). Near the peak of the flood, flows were increasing as rapidly as $28 \mathrm{~m}^{3} / \mathrm{s}$ over just a $15 \mathrm{~min}$ period. Substantial scouring, bed load movement, and removal of riverbed and bank vegetation occurred during the flood.

The last tracking occasion before the flood (8-9 March) located radio signals from 21 live trout in the Motupiko River. Subsequent tracking after the flood (7-8 April) found radio signals from 13 of these fish originating from beneath gravel banks, within debris piles and out in the flood plain, indicating that they had been killed during the flood. Six fish survived the flood, and signals from two fish alive before the flood were not located again. Assuming that the 21 radiotagged fish living in the Motupiko River before the flood were a representative sample of the total adult trout population living in the Motupiko River, then the flood is estimated to have killed $60-70 \%$ of the adult trout population.

\section{Discussion}

\section{Fish Movement}

Most of the radio-tagged trout in our study were relatively sedentary, although some were more mobile, traveling up to $41 \mathrm{~km}$ during the study. This pattern is consistent with many earlier studies of river resident salmonids (Solomon and Templeton 1976; Diana et al. 2004; Gresswell and Hendricks 2007). We found these two strategies are not fixed for particular members of the populations - that is, previously sedentary fish becoming mobile or previously mobile fish becoming more sedentary (also noted by Harcup et al. 1984). The availability of suitable habitat seemed to be an 


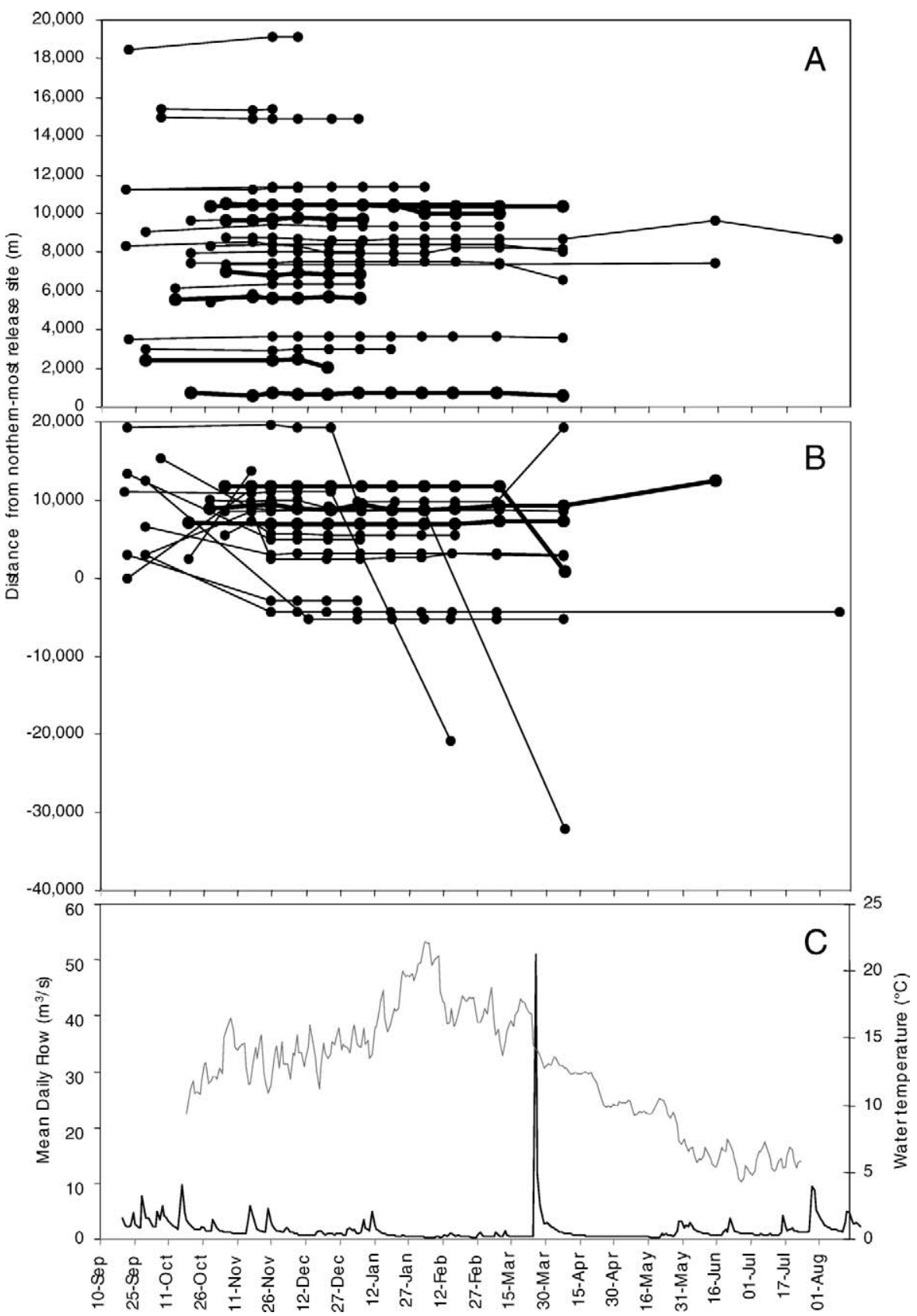

FIGURE 2.-Timelines from the release of radio-tagged brown trout in the Motupiko River for (A) fish that changed position by less than 1,000 $\mathrm{m}$ between radio-tracking surveys and (B) fish that changed position more than 1,000 $\mathrm{m}$. Point zero on the $y$-axis is the downstream-most release location; positive values are upstream of this point and negative values are downstream. The heavy lines denote females, the light lines males. Panel (C) shows the mean daily flow (heavy line) and water temperature (light line) at the recorder sites. 


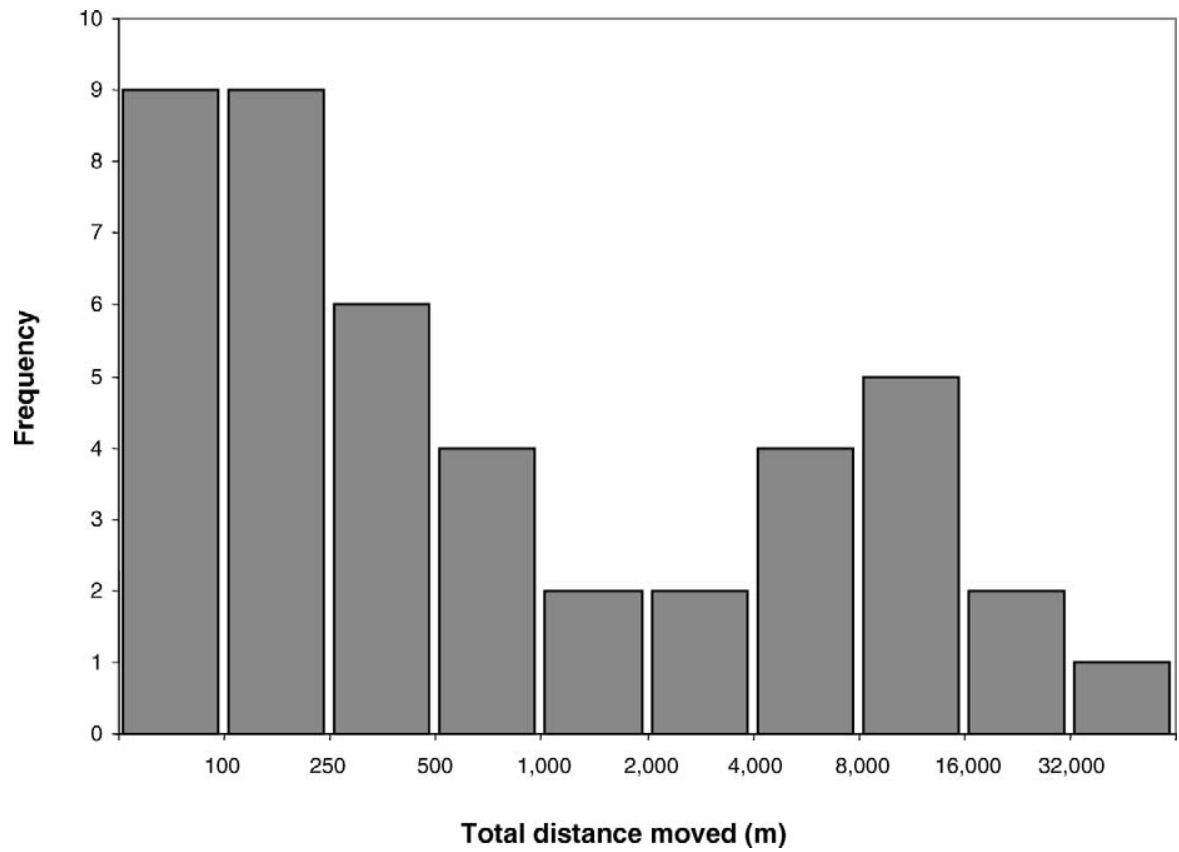

FIGURE 3.-Frequency histogram (number of fish) of the total distance moved by 44 radio-tagged brown trout in the Motupiko River during the 11-month study.

important feature influencing the locations where sedentary fish were found. In all cases the fish that remained within the Motupiko River throughout the summer were occupying relatively deep pools $(>1.2$ $\mathrm{m})$. The importance of deep water for supporting adult brown trout (Heggenes 1988; Young 1995) and juvenile salmonids (Bjornn and Reiser 1991) is well known. Pools provide deep water refuge, cover, and potentially cooler water, especially during low-flow periods (Elliott 2000; Ebersole et al. 2003; Olsen and Young 2009).

\section{Rates of Movement}

Movement rates of river-resident trout appear to vary widely, but our observations of $0-801 \mathrm{~m} / \mathrm{d}$ were within the range reported previously for nonspawning brown trout (Young 1994; Strickland et al. 1999; Bettinger and Bettoli 2004). Faster movement has been recorded for brown trout moving upstream to spawning grounds (Ovidio et al. 2002; Rustadbakken et al. 2004; Svendsen et al. 2004) and also downstream after spawning (Rustadbakken et al. 2004). The movement rates we observed were also similar to the range of movement rates reported for spawning rainbow trout Oncorhynchus mykiss in New Zealand (321-487 m/d; Dedual and Jowett 1999; Venman and Dedual 2005), but lower than that reported for bull trout Salvelinus confluentus (up to $4.4 \mathrm{~km} / \mathrm{d}$; Swanberg 1997).
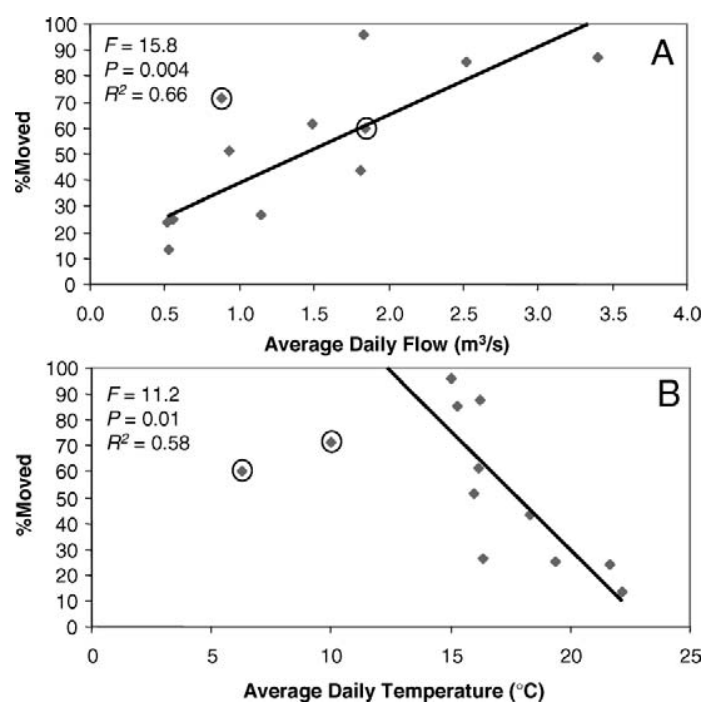

FIGURE 4.- Relationships between the percentage of radiotagged brown trout in the Motupiko River that moved more than $15 \mathrm{~m}$ between tracking occasions and (A) the mean daily flow and (B) the average daily water temperature. The number of trout tracked on each occasion (data points) ranged from 16 to 41 . The circled points denote the few fish left alive after the large flood of March 2005, which were not included in the regression analyses. The regressions were based on transformed data, but the figure shows untransformed data. 
The total distances moved by brown trout in our study (up to $41 \mathrm{~km}$ ) were also within the range reported elsewhere for brown trout (Allen 1951; Clapp et al. 1990; Meyers et al. 1992; Burrell et al. 2000; Knouft and Spotila 2002; Ovidio et al. 2002; Bettinger and Bettoli 2004; Diana et al. 2004; Rustadbakken et al. 2004; Heggenes et al. 2007), although somewhat less than the 76-202 km reported by Young (1994), Wilson and Boubee (1996), and Strickland et al. (1999). Maximum movements are presumably constrained by the size of the catchments studied and the distances among foraging, refuge and spawning habitats. Nevertheless, large-scale movements by a component of brown trout populations and other stream salmonids appear to be a common life history strategy (Gowan et al. 1994).

\section{Male Trout Bias}

Our sample of trout was heavily biased toward males ( $77 \%$ of sample), which is typical of headwater brown trout fisheries in New Zealand (Jellyman and Graynoth 1994). This male bias suggests that many of the females involved with spawning in the previous autumn and winter may have already migrated downstream before our capture and tagging in spring. Fast downstream movement after spawning has been reported previously (Meyers et al. 1992; Burrell et al. 2000), and it is possible that the few female trout we sampled were remnants of a larger group of females that had departed the Motupiko River after spawning.

\section{Factors Affecting Movement}

We initially hypothesized that the rate of movement would be relatively low until environmental variables reached threshold values that triggered movement. However, this pattern was not observed, and rates of movement declined steadily over the spring-summer period as flows decreased and water temperatures increased (Figure 4). It is difficult to separate the effects of flow and temperature on rates of movement because they were somewhat correlated $(r=-0.42)$. This pattern appears to be typical for trout; that is, relatively low rates of movement have been reported during periods with high temperatures (Burrell et al. 2000; Mellina et al. 2005; Gresswell and Hendricks 2007). Energetic costs of migration and movement increase for brown trout with water temperature and are extreme when water temperatures exceed $19^{\circ} \mathrm{C}$ (Elliott 1994). We expected increased rates of movement in autumn, in preparation for spawning (as reported by Solomon and Templeton 1976; Burrell et al. 2000; Bettinger and Bettoli 2004); however, very few of our tagged trout were left alive after the large flood in early autumn, making conclusions about prespawning movement impossible.

\section{Flood-Induced Mortality}

Our results suggest that at least $60 \%$ of the adult trout population in the Motupiko River were killed during the large flood near the end of our study. Such high mortality rates have been suggested elsewhere by studies examining changes in fish abundance before and after floods. Following floods, for example, Jowett and Richardson (1989) reported adult brown trout abundance decreased by $26-57 \%$ in six of the seven rivers they studied (flood return period, 20-500 years), and Carline and McCullough (2003) reported an 84\% reduction in abundance of age-1 and older brook trout Salvelinus fontinalis. Seegrist and Gard (1972) reported similar results for rainbow trout and brook trout, and for one flood there was an $82 \%$ decline, albeit they found little effect of an earlier flood in the same system.

Most studies of the effects of floods on fish populations have shown that adult trout are less severely impacted than juveniles (Allen 1951; Seegrist and Gard 1972; Jowett and Richardson 1989; LobonCervia 1996; Harvey et al. 1999; Jensen and Johnsen 1999). We actually observed a similar reduction (65\%) in juvenile brown trout abundance, resulting from the same March 2005 flood in the Rainy River, a tributary of the Motupiko River (J. Hay and J. W. Hayes, unpublished data). Channel morphology appears to influence the effects of floods on salmonids, greatest changes in abundance occurring at sites where bed load movement and geomorphic changes occur (Lamberti et al. 1991; Pearsons et al. 1992; Nislow et al. 2002). Substantial bed load movement and removal of riverbed and bank vegetation were evident in the Motupiko and Rainy rivers as a result of the flood.

In the above-cited studies, it is not clear whether the drop in abundance associated with floods was due to displacement or direct flood-induced mortality. Trout can die because of physical injury caused by substrate movement, or after being stranded in remnant pools on the riverbed or floodplain (Jowett 1997; Ortlepp and Murle 2003). Another potential mechanism of mortality, suggested by our study, may be burial by largescale substrate movement, although we cannot be sure whether the fish located beneath substrate and debris following the flood were dead before burial. Trout may also be swept downstream or out to sea. Some studies have indicated that fish displaced downstream by floods have returned upstream during the flood recession (Dedual and Jowett 1999; Dare et al. 2002; Ortlepp and Murle 2003). As far as we are aware, there are few direct observations of trout mortality resulting 
from floods (but see Ortlepp and Murle 2003). Our results confirm that flood-induced mortality can occur and affect a substantial proportion of an adult trout population.

\section{Acknowledgments}

We thank Ricky Olley, Rowan Strickland, and Aaron Quarterman for logistical assistance during the study. We also appreciated the support and encouragement from Lawson Davey, Rhys Barrier, and Neil Deans from Fish and Game New Zealand, along with members of the Nelson Angling Club who helped us catch the trout. We also acknowledge the Tasman District Council for supplying flow data. This work was funded by the New Zealand Foundation for Research Science and Technology as part of the Integrated Catchment Management Project (Contract C09X0305). Two anonymous reviewers provided helpful comments on an earlier version of this manuscript.

\section{References}

Allen, K. R. 1951. The Horokiwi stream: a study of a trout population. New Zealand Marine Department Fisheries Bulletin 10.

Basher, L. R. 2003. The Motueka and Riwaka catchments: a technical report summarising the present state of knowledge of the catchments, management issues, and research needs for integrated catchment management. Landcare Research, Lincoln, New Zealand.

Bettinger, J. M., and P. W. Bettoli. 2004. Seasonal movement of brown trout in the Clinch River, Tennessee. North American Journal of Fisheries Management 24:1480 1485.

Bjornn, T. C., and D. W. Reiser. 1991. Habitat requirements of salmonids in streams. Pages 83-138 in W. R. Meehan, editor. Influences of forest and rangeland management on salmonid fishes and their habitats. American Fisheries Society, Special Publication 19, Bethesda, Maryland.

Brown, R. S., S. J. Cooke, W. G. Anderson, and R. S. McKinley. 1999. Evidence to challenge the "2\% rule" for biotelemetry. North American Journal of Fisheries Management 19:867-871.

Brown, R. S., D. R. Geist, K. A. Deters, and A. Grassell. 2006. Effects of surgically implanted acoustic transmitters $>2 \%$ of body mass on the swimming performance, survival, and growth of juvenile sockeye and Chinook salmon. Journal of Fish Biology 69:1626-1638.

Burrell, K. H., J. J. Isely, D. B. Bunnell, D. H. VanLear, and C. A. Dolloff. 2000. Seasonal movement of brown trout in a southern Appalachian river. Transactions of the American Fisheries Society 129:1373-1379.

Carline, R. E., and B. J. McCullough. 2003. Effects of floods on brook trout populations in the Monongahela National Forest, West Virginia. Transactions of the American Fisheries Society 132:1014-1020.

Clapp, D. F., R. D. Clark, and J. S. Diana. 1990. Range, activity, and habitat of large, free-ranging brown trout in a Michigan stream. Transactions of the American Fisheries Society 119:1022-1034.

Cunjak, R. A. 1996. Winter habitat of selected stream fishes and potential impacts from land-use activity. Canadian Journal of Fisheries and Aquatic Sciences 53:267-282.

Dare, M. R., W. A. Hubert, and K. G. Gerow. 2002. Changes in habitat availability and habitat use and movements by two trout species in response to declining discharge in a regulated river during winter. North American Journal of Fisheries Management 22:917-928.

Dedual, M., and I. G. Jowett. 1999. Movement of rainbow trout (Oncorhynchus mykiss) during the spawning migration in the Tongariro River, New Zealand. New Zealand. Journal of Marine and Freshwater Research 33:107-117.

Diana, J. S., J. P. Hudson, and R. D. Clark. 2004. Movement patterns of large brown trout in the mainstream Au Sable River, Michigan. Transactions of the American Fisheries Society 133:34-44.

Ebersole, J. L., W. J. Liss, and C. A. Frissell. 2003. Thermal heterogeneity, stream channel morphology, and salmonid abundance in northeastern Oregon streams. Canadian Journal of Fisheries and Aquatic Sciences 60:1266-1280.

Elliott, J. M. 1994. Quantitative ecology and the brown trout. Oxford University Press, Oxford, UK.

Elliott, J. M. 2000. Pools as refugia for brown trout during two summer droughts: trout responses to thermal and oxygen stress. Journal of Fish Biology 56:938-948.

Gowan, C., and K. D. Fausch. 2002. Why do foraging stream salmonids move during summer? Environmental Biology of Fishes 64:139-153.

Gowan, C., M. K. Young, K. D. Fausch, and S. C. Riley. 1994. Restricted movement in resident stream salmonids: a paradigm lost?. Canadian Journal of Fisheries and Aquatic Sciences 51:2626-2637.

Gresswell, R. E., and S. R. Hendricks. 2007. Population-scale movement of coastal cutthroat trout in a naturally isolated stream network. Transactions of the American Fisheries Society 136:238-253.

Harcup, M. F., R. Williams, and D. M. Ellis. 1984. Movements of brown trout, Salmo trutta L., in the River Gwyddon. South Wales Journal of Fish Biology 24: 415-426.

Harvey, B. C., R. J. Nakamoto, and J. L. White. 1999. Influence of large woody debris and a bankfull flood on movement of adult resident coastal cutthroat trout (Oncorhynchus clarki) during fall and winter. Canadian Journal of Fisheries and Aquatic Sciences 56:2161-2166.

Hayes, J. W. 1995. Spatial and temporal variation in the relative density and size of juvenile brown trout in the Kakanui River, North Otago, New Zealand. New Zealand Journal of Marine and Freshwater Research 29:393-407.

Heggenes, J. 1988. Physical habitat selection by brown trout (Salmo trutta) in riverine systems. Nordic Journal of Freshwater Research 64:74-90.

Heggenes, J., O. K. Omholt, J. R. Kristiansen, J. Sageie, F. Okland, J. G. Dokk, and M. C. Beere. 2007. Movements by wild brown trout in a boreal river: response to habitat and flow contrasts. Fisheries Management and Ecology $14: 333-342$.

Hughes, N. F. 1998. A model of habitat selection by drift- 
feeding stream salmonids at different scales. Ecology 79:281-294.

Hughes, N. F. 1999. Population processes responsible for larger-fish-upstream distribution patterns of Arctic grayling (Thymallus arcticus) in interior Alaskan runoff rivers. Canadian Journal of Fisheries and Aquatic Sciences 56:2292-2299.

Hughes, N. F., J. W. Hayes, K. A. Shearer, and R. G. Young. 2003. Testing a model of drift feeding using threedimensional videography of wild brown trout, Salmo trutta, in a New Zealand river. Canadian Journal of Fisheries and Aquatic Sciences 60:1462-1476.

Jellyman, D. J., and E. Graynoth. 1994. Headwater trout fisheries in New Zealand. National Institute of Water and Atmospheric Research, Freshwater Research Report 12, Christchurch.

Jensen, A. J., and B. O. Johnsen. 1999. The functional relationship between peak spring floods and survival and growth of juvenile Atlantic salmon (Salmo salar) and brown trout (Salmo trutta). Functional Ecology 13:778785 .

Jepsen, N., K. Anders, E. B. Thorstad, and E. Baras. 2002. Surgical implantation of telemetry transmitters in fish: how much have we learned?. Hydrobiologia 483:239_ 248.

Jowett, I. 1997. Environmental effects of extreme flows. Pages 103-116 in M. P. Mosley and C. P. Pearson, editors. Floods and droughts: the New Zealand experience. New Zealand Hydrological Society, Wellington.

Jowett, I. G., and J. Richardson. 1989. Effects of a severe flood on instream habitat and trout populations in seven New Zealand rivers. New Zealand Journal of Marine and Freshwater Research 23:11-17.

Jowett, I. G., and J. Richardson. 1994. Comparison of habitat use by fish in normal and flooded river conditions. New Zealand Journal of Marine and Freshwater Research 28:409-416.

Knouft, J. H., and J. R. Spotila. 2002. Assessment of movements of resident stream brown trout, Salmo trutta L., among contiguous sections of stream. Ecology of Freshwater Fish 11:85-92.

Lamberti, G. A., S. V. Gregory, L. R. Ashkenas, R. C. Wildman, and K. M. S. Moore. 1991. Stream ecosystem recovery following a catastrophic debris flow. Canadian Journal of Fisheries and Aquatic Sciences 48:196-208.

Lobon-Cervia, J. 1996. Response of a stream fish assemblage to a severe spate in northern Spain. Transactions of the American Fisheries Society 125:913-919.

Meka, J. M., E. E. Knudsen, D. C. Douglas, and R. B. Benter. 2003. Variable migratory patterns of different adult rainbow trout life history types in a southwest Alaska watershed. Transactions of the American Fisheries Society 132:717-732.

Mellina, E., S. G. Hinch, and K. D. MacKenzie. 2005. Seasonal movement patterns of stream-dwelling rainbow trout in north-central British Columbia, Canada. Transactions of the American Fisheries Society 134:10211037.

Meyers, L. S., T. F. Thuemler, and G. W. Kornely. 1992. Seasonal movement of brown trout in northeast Wisconsin. North American Journal of Fisheries Management 12:433-441.
Natsumeda, T. 2003. Effects of a severe flood on the movements of Japanese fluvial sculpin. Environmental Biology of Fishes 68:417-424.

Nielsen, J. L., T. E. Lisle, and V. Ozark. 1994. Thermally stratified pools and their use by steelhead trout in northern Californian streams. Transactions of the American Fisheries Society 123:613-626.

Nislow, K. H., F. J. Magilligan, C. L. Folt, and B. P. Kennedy. 2002. Within-basin variation in the short-term effects of a major flood on stream fishes and invertebrates. Journal of Freshwater Ecology 17:305-318.

Northcote, T. G. 1992. Migration and residency in stream salmonids: some ecological considerations and evolutionary consequences. Nordic Journal of Freshwater Research 67:5-17.

Olley, R. 2008. Recruitment and migration in Motueka River brown trout revealed by otolith trace element analysis. Master's thesis. University of Otago, Dunedin, New Zealand.

Olsen, D. A., and R. G. Young. 2009. Significance of riveraquifer interactions for reach-scale thermal patterns and trout growth potential in the Motueka River. New Zealand. Hydrogeology Journal 17:175-186.

Ortlepp, J., and U. Murle. 2003. Effects of experimental flooding on brown trout (Salmo trutta fario L.): the River Spol, Swiss National Park. Aquatic Sciences 65:232-238.

Ovidio, M., E. Baras, D. Goffaux, F. Giroux, and J. C. Philippart. 2002. Seasonal variations of activity pattern of brown trout (Salmo trutta) in a small stream, as determined by radiotelemetry. Hydrobiologia 470:195202.

Ovidio, M., J. C. Philippart, and E. Baras. 2000. Methodological bias in home range and mobility estimates when locating radio-tagged trout, Salmo trutta, at different time intervals. Aquatic Living Resources 13:449-454.

Pearsons, T. N., H. W. Li, and G. A. Lamberti. 1992. Influence of habitat complexity on resistance to flooding and resilience of stream fish assemblages. Transactions of the American Fisheries Society 121:427-436.

Richardson, J., M. J. Unwin, and L. D. Teirney. 1984. The relative value of Nelson rivers to New Zealand anglers. New Zealand Ministry of Agriculture and Fisheries, Fisheries Environmental Report 45, Wellington.

Rodriguez, M. A. 2002. Restricted movement in stream fish: the paradigm is incomplete, not lost. Ecology 83:1-13.

Roghair, C. N. 2005. Brook trout movement during and after recolonization of a naturally defaunated stream reach. North American Journal of Fisheries Management 25:777-784.

Rustadbakken, A., J. H. L'AbeeLund, J. V. Arnekleiv, and M. Kraabol. 2004. Reproductive migration of brown trout in a small Norwegian river studied by telemetry. Journal of Fish Biology 64:2-15.

Schwartz, J. S., and E. E. Herricks. 2005. Fish use of stagespecific fluvial habitats as refuge patches during a flood in a low-gradient Illinois stream. Canadian Journal of Fisheries and Aquatic Sciences 62:1540-1552.

Seegrist, D. W., and R. Gard. 1972. Effects of floods on trout in Sagehen Creek, California. Transactions of the American Fisheries Society 101:464-478.

Solomon, D. J., and R. G. Templeton. 1976. Movements of 
brown trout Salmo trutta L. in a chalk stream. Journal of Fish Biology 9:411-423.

Strickland, R. R., J. W. Hayes, and P. Barter. 1999. Wairau River brown trout radio-tracking study. Cawthron Institute, Cawthron Report 505, Nelson, New Zealand.

Svendsen, J. C., A. Koed, and K. Aarestrup. 2004. Factors influencing the spawning migration of female anadromous brown trout. Journal of Fish Biology 64:528-540.

Swanberg, T. R. 1997. Movements of and habitat use by fluvial bull trout in the Blackfoot River, Montana. Transactions of the American Fisheries Society 126:735-746.

Venman, M. R., and M. Dedual. 2005. Migratory behaviour of spawning rainbow trout (Oncorhynchus mykiss) in the Tongariro River, New Zealand, after habitat alteration. New Zealand Journal of Marine and Freshwater Research 39:951-961.

Walker, R. V., K. W. Myers, N. D. Davis, K. Y. Aydin, K. D. Friedland, H. R. Carlson, G. W. Boehlert, S. Urawa, Y. Ueno, and G. Anma. 2000. Diurnal variation in thermal environment experienced by salmonids in the North
Pacific as indicated by data storage tags. Fisheries Oceanography 9:171-186.

Wilson, B. J., and J. A. T. Boubee. 1996. The seasonal movements of large brown trout in the lower Waikato River system. Pages 85-101 in M. A. Rodway, editor. Proceedings of the Lake Fisheries Workshop. New Zealand Fish and Game Council, Wellington.

Young, M. K. 1994. Mobility of brown trout in south-central Wyoming streams. Canadian Journal of Zoology 72:2078-2083.

Young, M. K. 1995. Telemetry-determined diurnal positions of brown trout (Salmo trutta) in two south-central Wyoming streams. American Midland Naturalist 133:264-273.

Young, M. K. 1996. Summer movements and habitat use by Colorado River cutthroat trout (Oncorhynchus clarki pleuriticus) in small, montane streams. Canadian Journal of Fisheries and Aquatic Sciences 53:1403-1408.

Young, M. K., R. A. Wilkison, J. M. Phelps, and J. S. Griffith. 1997. Contrasting movement and activity of large brown trout and rainbow trout in Silver Creek, Idaho. Great Basin Naturalist 57:238-244. 